UDC $622.831: 622.283: 622.333$

\title{
炭鉱の立坑ライニングの応力の測定*
}

$\begin{array}{llll}\text { 正会員 平 松 } & \text { 良 } & \text { 雄 }^{* *} \\ \text { 正会員 岡 } & & \text { 行 } & \text { 俊 }^{* * *}\end{array}$

\section{Measuring Stress in Shaft Linings Coal Mines}

Yoshio HIRAMATSU and Yukitoshi OKA

\begin{abstract}
For the purpose of contributing to the design of shaft linings, especially of coal mines, the authors have attempted to measure the stress in the shaft linings in several coal mines in Japan with the photoelastic apparatus contrived by them.

The results show that the lining in a solid ground is generally subjected to but a low stress, but sometimes to a stress about $30 \mathrm{~kg} / \mathrm{cm}^{2}$, that in a crushed ground the lining is subjected to a medium or high stress fluctuating, and that in a loose ground there appears such an earth pressure acting on the outer surface of the lining that may be estimated by the formula of the soil pressure.
\end{abstract}

\section{1. 緒言}

立坑ライニングを設計するには，これにどれほどの地 圧が作用するかを知らなければならない。立坑の開さく される地盤が弾性岩盤であれば, その強さを知れば, 弾 性理論により立珫を開さくすることによつて起る地圧現 象を一応推定することはでき, またその地艋が土層, 塑 性地艋あるいは陂碎带などであれば, 内部摩擦係数を知 れば，一応地圧を見積ることはできる。しかし実際の岩 盤の性質や状態は複雑であるから, 理論的に適確に地圧 を推定することは，現状では不可能である。そこで寒際 の立坑ライニングについて応力の測定を行い，ライニン グに作用する地圧を知ることは極めて有意義なことと考 觉れる。

筆者らは数年前から, 光弾性を利用する応力計を研究 乙て来たが，昭和 27 年に手の平に楽に乘る小型の装置を 製作することに成功したので，当時三池鉱業所初島に拉 いて井筒沈下法によつて開さくされていた立坑井筒の応 力測定にこれを利用して頂いた。続いて田川, 大夕張, 砂川拈よび三井芦別の各鉣業所の協力を得て, 新しく開 さくされた立坑のライニングの応力を測定して頂くこと がでさた。これらの測定は, 最初に試作した応力計を用 いて行われたものであり，末た測定技術が未熟であつた ため，今から見れば精度は十分でなからた。その後この 光弾性応力計は改息され, 精度は向上した。改良後の装

* 昭和 35 年 2 月 22 日受理, 昭和 34 年11月 8 日, 昭和34年度日本鉱業 会秋季大会 (能本) 学術講演会にて揱演

** 工博, 京都大学教授 鉣山学教室

**** 京都大学助手
置は奔別鉱業所で最近開さくされた中央立坑ライニング の応力測定に利用して頂いた。

上に述べたように，多くの立坑に祘いて応力の測定が 行なわれたが，最近まで測定精度が低く，なかば定性的 なかば定量的な結果しか得られなかつたのは残念であっ た。しかし立坑ライニングの応力を測定できる機会は， 今後, しばしばあるわけではないから, 関係各会社抢よ び各鉱業所の許可を得て,一応ここに 7 年間の測定結果 の概要を報告し，ライニング設計上の参考資料とした い。な怙，今後精度の高い方法でこの種の測定が続けらら れ，一層信頼できる結果が得られることを希望する次第 である。

\section{2. 応力測定方法}

まず，立坑または立坑底のコンクリートライニングを 施工するとき，その表面に光学がラス製測定片を埋設し て拉く。埋設した直後は, ライニング内の応力は汪とん どゼロであるが，その後ライニングに地圧が作用して来 ると，その内部の応力も高息，したがつて測定片の応 力も高采る。そこで測定片の虑力を光弾性応力計を用い て測定し, ライニングの応力を求めるのである。

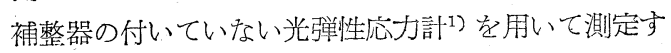
るには，まず中空測定片に現われる等色繶模様を肉眼で 観察して, 二つの主応力の比 $p: q$ を判定する。この判 定の基礎資料として, 理論計算に基ずいて製作した標淮

* さき有誌 71 巻 799 号 12 頁の第 1 拈よび第 2 図化, この種の等色 楾模栚を発表したが,この図は現場測定の基礎資料として精度が不 十分であることが分つたので，今回の諭文第1図は,さらに詳細な 計算を行なつて製作したものである。 


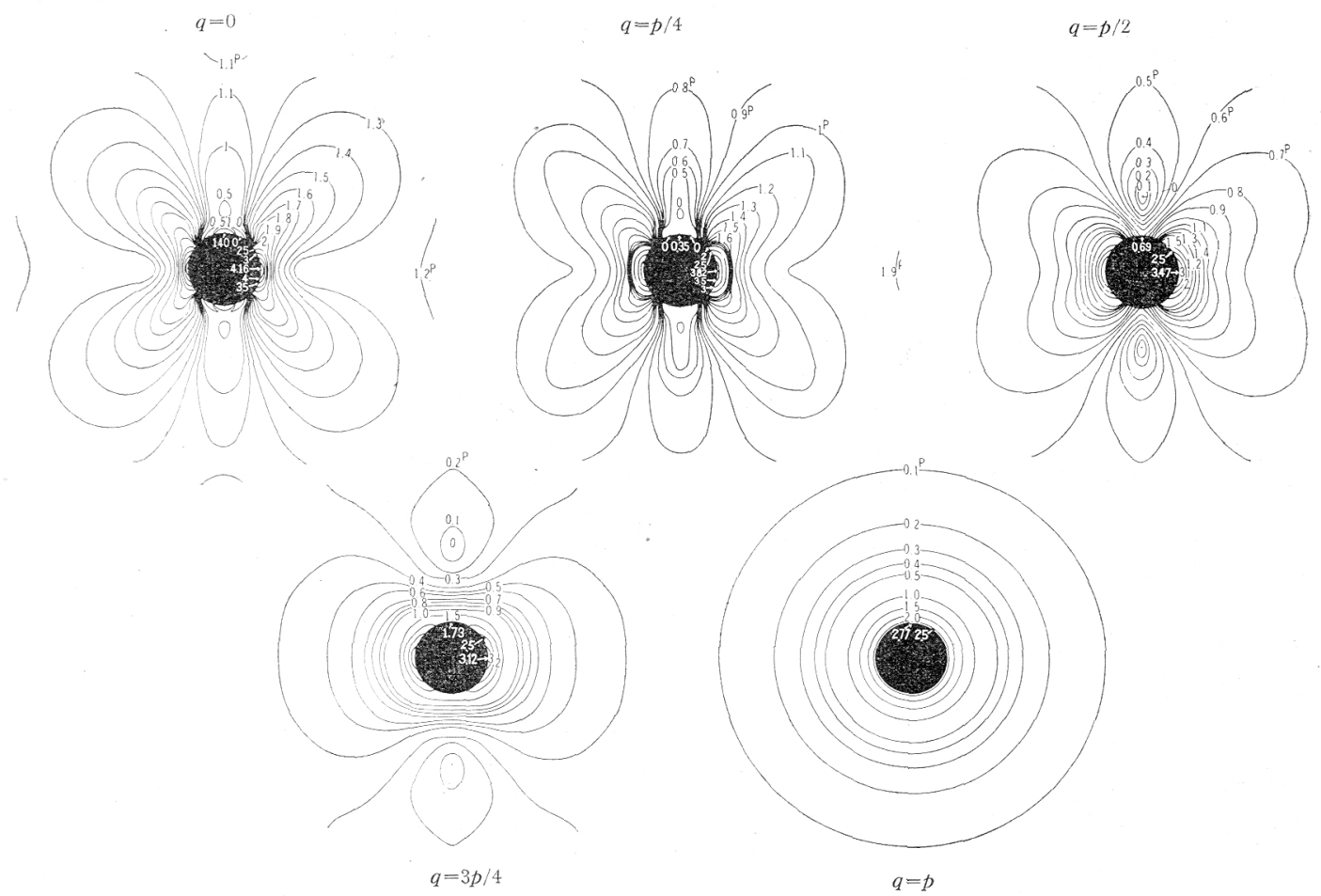

第1図 主応力比 $p: q$ を判定するた可の標準等色線模樣

等色線模様を示せば，第1図の上らで西る*。四の中に 記入した数字は各縞の主応力差を示したるので岗る。こ の図は等色線の形を示す代かりでな々，各々の縞化記入 された相対的店力から，任意のどれかの縞の色が分礼ば 他の縞の色索推定するのに役立つもので市る。も乙，1 軸広力で㐫る場合は，等任線縞の対称軸の方向を見活乙

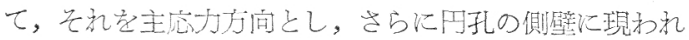

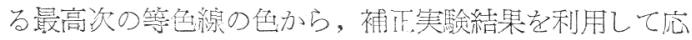

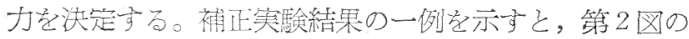

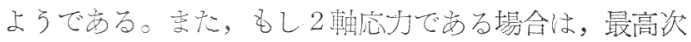
等色線の色とpとの関倸が $p: q$ の值汇よつて異なるか

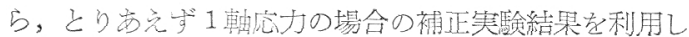

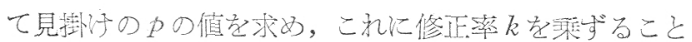

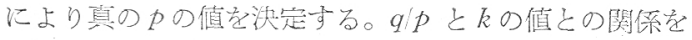

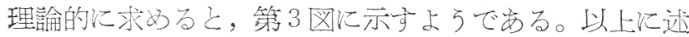

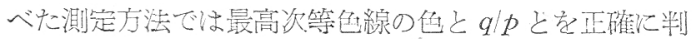
定するのが蜼しく，乙たがつて测定精度が高くない点 がある。

補整器の付いた光弾性岕才計を用いる場合, 定量的汇

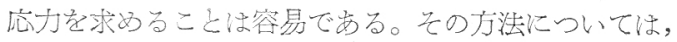
すで報告しているので，ここ汇説明すること省略す $3^{27,3 \gamma_{9}}$

なおコンクリートはかなりクリープを起すので，それ

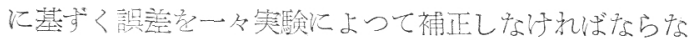

い。以下に報告する各立坑での応力測定においては, ク リープに基ずく愦差を補正していないことを批断りして 秝く。乙かし，光弾性応力計による応力測定では，他の ヒズミ在測定して応力学決定する方法と異なり，クリー プの影響は大きくないものと考光られる。

\section{3. 三池鉱業所初島排気立坑における測定}

初島は有明海上飞築島されたるので，排気立坑は深さ 約 $120 \mathrm{~m}$ の四紀膡の間で计井筒沈下法沉よつて開さくさ

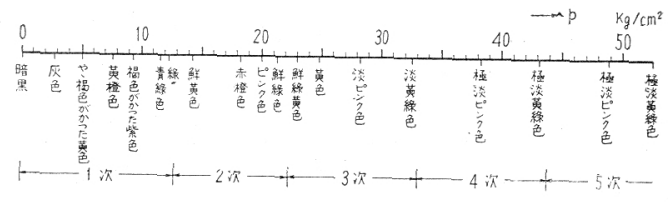

第2図コンクリー 卜棈造物江埋設され 危中空測定片飞現的 机る最高次等色線の 色之中之の関係の一 例

第 3 図

kと $q / p$ との関係

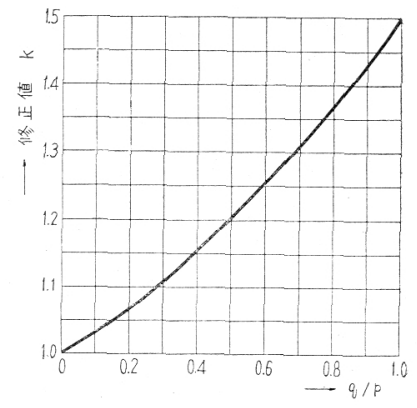


れた。この井筒作用する地圧を知るため，深さ $22 \mathrm{~m}$ ， $62.6 \mathrm{~m}, 82.6 \mathrm{~m}$ の 3 断面に, それぞれ東西南北の 4 個所 に測定片が埋設された。埋設の時期は井筒を地上で接ぎ 足すときであつて，第 4 龱沅すように，昭和27年11月 から同28年 5 月までの間であつた。

この立坑の工事中は, 内部に泥水が满らていて全然応 力の測定はできなかつた。昭和29年 1 月に行なわれた測

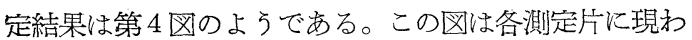
れた等色線模様のスケッチ，主応力方问特よび主応力な ぞを示している。深さ $22 \mathrm{~m}$ の断面では, 応力が低過ぎて, 応力の判定が難しかつた。どの測定も，浮涪1 軸応力状 態にあつて, 主応力方尚は水平皂たは水平近い。乙か し, 同一断面上の 4 測点の応力状態には，いくらか偏差 が認められる。井筒汇鉛直方向の地圧が現われないこと から，井筒の自重は井筒と地盤との間の摩擦により大体 支觉られているものと考完られる。

仮りに, 井筒の内壁には測定された最大主応力の平均 值に等しい水平方向の応力 $\sigma_{\theta}$ が生じているるのとすれ ば，井筒の外壁に垂直にかかる地圧 $p$ は次式で計算でき る4)。

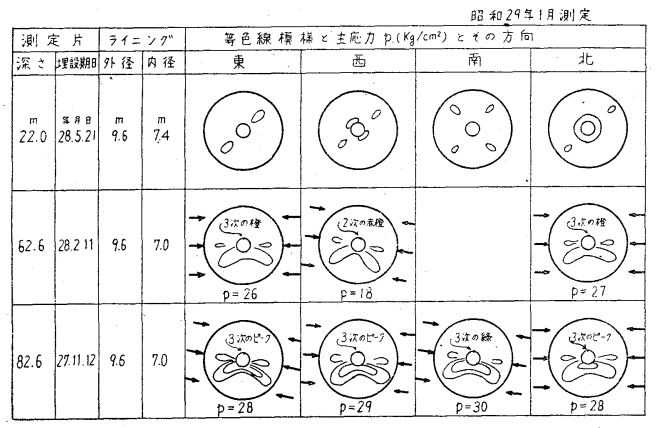

第 4 図 三池鈗業所初島排気立坑井筒 に打ける測定結果
第 1 表

\begin{tabular}{|c|c|c|c|}
\hline${ }_{\text {(m) }}$ e & $\begin{array}{c}\text { 茾筒内壁面上の永 } \\
\text { 平方向の均応力 } \\
\mathrm{kg} / \mathrm{cm}^{2}\end{array}$ & $\begin{array}{l}\text { (1) 式による地圧 } \\
\mathrm{kg} / \mathrm{cm}^{2}\end{array}$ & 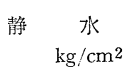 \\
\hline $\begin{array}{l}62.6 \\
82.6\end{array}$ & $\begin{array}{l}23.7 \\
28.8\end{array}$ & $\begin{array}{l}5.55 \\
6.74\end{array}$ & $\begin{array}{l}6.25 \\
8.26\end{array}$ \\
\hline
\end{tabular}

$$
p=\frac{\sigma_{\theta}}{2}\left(1-\frac{r_{1}^{2}}{r_{2}^{2}}\right)
$$

ここに $r_{1}, r_{2}$ はそれれ゙れ井筒の内半径，外半径である。 深さ $22.0 \mathrm{~m}$ の断面の測定值は除外し，深さ $62.6 \mathrm{~m}$ と 82.6 $\mathrm{m}$ の二つの断面について，(1)式から求めた地圧とそれ ぞれの深さの静水圧とを示せば，第 1 表のようである。 この結果によれば，地圧は静水圧よりいくぶん低い。ま た，この值は，地盤の比重量を $2,000 \mathrm{~kg} / \mathrm{m}^{3}$, 内部摩擦角 を約 $24^{\circ}$ として, Rankine の土圧公式で計算した值と， ほぼー致する。な挍流砂層中の地圧は静水圧の 1.3 倍程 度（最大值は 1.7 倍に達する）とのことである5)。

\section{4. 田川鉱業所伊加利立坑底における測定}

伊加利立坑は深さ約 $660 \mathrm{~m}$ で，良好な岩盤中に開さく されたから，地圧の点から見てあ委り問題はなかつた。 しかし，坑底連接部に和いて，中央から上方にれき(礫) 岩, 下方に弱、貣岩層が現われたので, これ粑性コン クリートライニングを施したとき，時間の経過ととすに 高い地圧がかかつて来はしないかという眯念があつた。 そこで坑底のライニングに約20個の測定片を埋設して応 力を測定し，地圧のかかり方を監視することになつた。 第 5 四は坑底坑道の中心線を通る縱断面図で, 肩側から 深側を見たものである。走向は坑道の中心線に平行で傾， 斜は $15^{\circ}$ である。坑底の支保は，まずレールのリング枠 を入れ，これ值角に上方には鉄筋を，下方にはレール を入れて補強し，これを包んでコンクリートを打つたも のである。コンクリートの厚さは，上方は約 $50 \mathrm{~cm} ， 下$

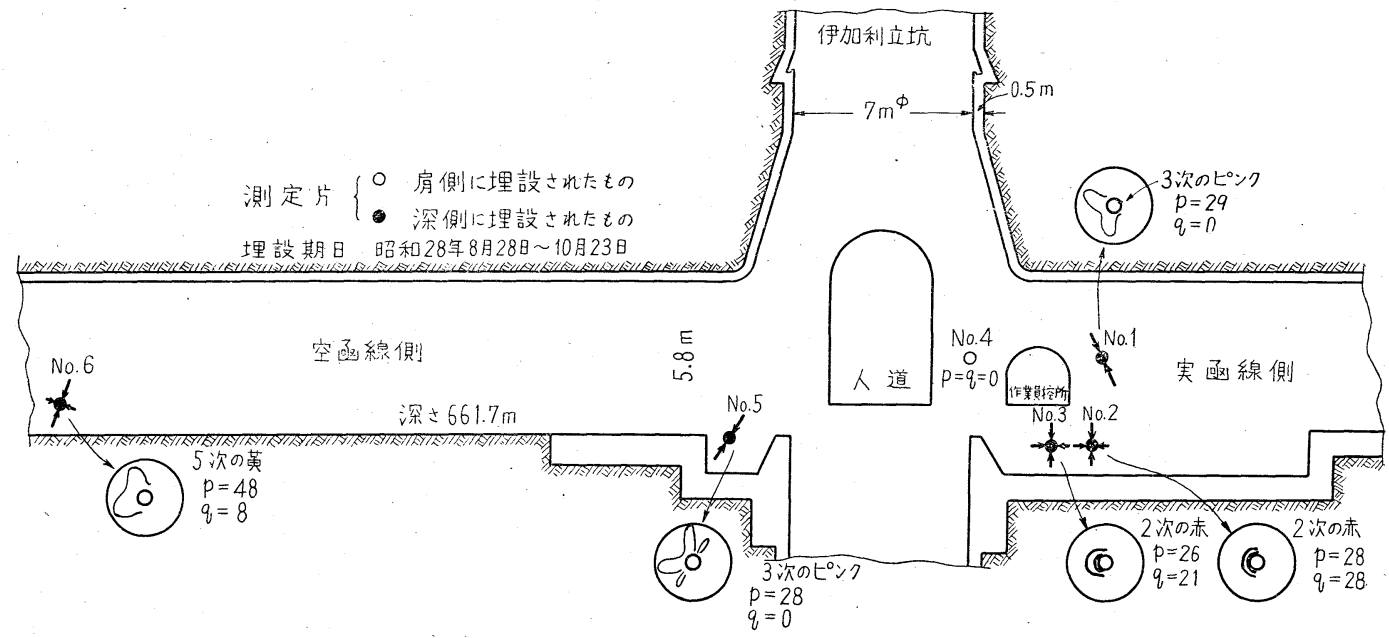

第 5 図 伊加利立坑坑底構造技よび昭和34年11月に括ける測定結果 
方は約 $1 \mathrm{~m}$ である

測定片の埋設は昭和 29 年 8 月 28 日から 10月23日の間に行なわれた。これらの測 定片について，測定したところによれば ライニングの応力は, 初めの中は, ある 程度増加するが，やがて変化しなくなる ことを認め, この様子ではライニングは 十分安全に維持されるものと想像され た。その後長く浿定は行なわれなかつた がライニシグ施工後 5 年以上経過した昭 和34年11月に再び測定を試みた。測定片 の大部分はと(鍍)銀面が腐蝕したり, 充 填材料であるセメントモルタルの砂粒が 大きかつたためか，破損したりしていて

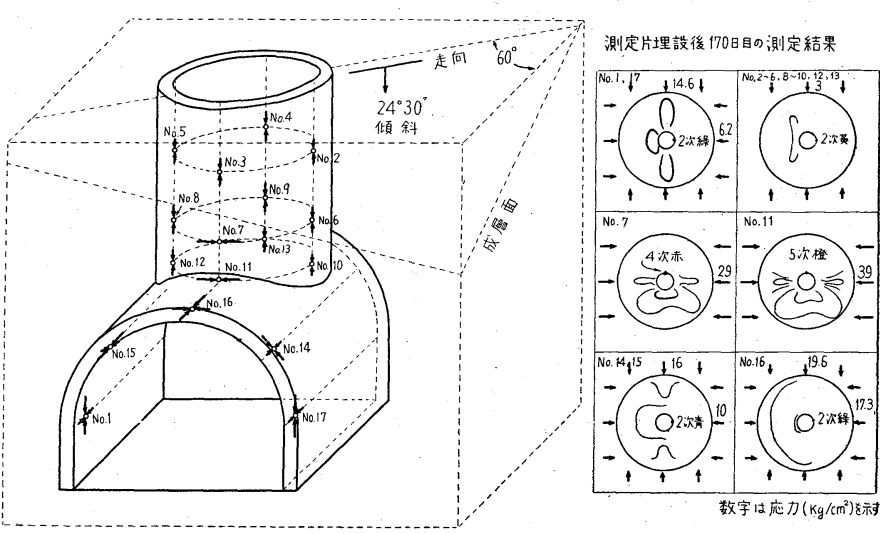

第 6 図 大夕張排気立坑の試験用坑底連接部の構 造と測定片埋設位置ならびに測定結果

第 2 表 幌加別頁岩の強度試験結果

測定ができた測定片の位置，主応力方向，等色腺模様拈 よび主応力は第 5 図汇記入した通りである。等色線のス ケッチは断面の半分だけについて示している。測定片 4 はライニングが坑底空間成形のため肉厚となり, 突出し ている部分で, 応力は答である。測定片 1,5 括よび 6 は いずれも主応力が傾斜していることを示し，最大主応力 は約 $30 \sim 50 \mathrm{~kg} / \mathrm{cm}^{2}$ である。測定片 2 扤よび 3 は坑道の 下方の壁面に埋められたもので，この付近は二つの主応 カが注淁しいことを等している。

この測定は, 施工から 5 年以上経過した後の応力変化 を知ることができた点に意義がある。

\section{5. 大夕張礦業所排気立坑における測定}

この立坑は深さ $760 \mathrm{~m}$ の坑底に预いて, 同径の $6 \mathrm{~m}$ の 円形沆道と連接する。その付近の岩盤は軟弱な幌加別頁 岩層で, 従来この地層中に開さくされた坑道の維持には かなり困難を感じていた核どである。第 2 表はこの頁岩 の強度試験結果である。

そこで，あらかじめ坑底連接部の位置に，坑底玾道の 導坑を利用して実物の $1 / 2$ の寸法で試験用の連接部を作 り，これに厚さ $20 \mathrm{~cm}$ のコンクリートライニングを施 し, その壁面に多数の測定片を埋設して, 昭和 29 年 5 月 28日から 170 日にわたつて応力変化を測定した。

第 6 図は試験用連接部の形, 測定片の位.㯰, 埋設後 170 日目の等色線模様, 主応力方间和よび主応力などを示 す。またライニング上の代表的籄所に和ける応力の時間 的変化は第 7 図に示すようである。この測定によれば, ライニングに作用する地圧は経過日数と共に増加し, 170 日位ではまだ落着いていないことが分る。しかし，分岐 部分の天井の角を除いては，ライニングの応力は $30 \mathrm{~kg}$

* 最近, 測定片の埋設方法の改良てより，このような故障はなくな つた。(文献 ( 2 )参照)

\section{管}

\begin{tabular}{|c|c|c|c|c|c|c|}
\hline \multirow{2}{*}{ 方 } & \multicolumn{3}{|c|}{ 圧 縮 試 験 } & \multicolumn{3}{|c|}{ 珐 裂 試 験 } \\
\hline & 試 験片 数 & 压縮強 & $\mathrm{c} \frac{\mathrm{kg}}{\mathrm{cm}^{2}}$ & 陚験片数 & 引張強 & $\mathrm{e} \frac{\mathrm{kg}}{\mathrm{cm}^{2}}$ \\
\hline 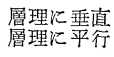 & $\begin{array}{l}2 \\
2\end{array}$ & & $\begin{array}{l}390 \\
486\end{array}$ & $\begin{array}{l}3 \\
2\end{array}$ & & 34 \\
\hline
\end{tabular}

$/ \mathrm{cm}^{2}$ 以下で, 今後増加するとしてあ, さほど問題にな るようなことはなかろうと想像された。ただ分岐部分の 天井の角の応力は最初急激に増加したが, 一たん, 注と んど零近くまで低下し，その後再び増加した。これは分 岐部分の天井の角は甚だ浮き易く，そのためライニング を圧迫していたが，一たん滑りが起つたため，ライニン グの他の部分に荷重がかかるようになつたことによるも のと思われる。筆者らは，さきにバロダイナミック実験 によつて, ライニングのない立坑底連接部の地圧現象に ついて研究したが, その結果によれば, やばり分岐部分 の天井の角が最も破壊しやすく，また，たとえここに崩 落が起つても，破壊は局部的に止まり，大きく拡大する ことはないことを認めた6)。この実験結果は上記の実測 結果とつじつまが合う。

この実㵋結果で注目されるるら一つの点は, 切上り部

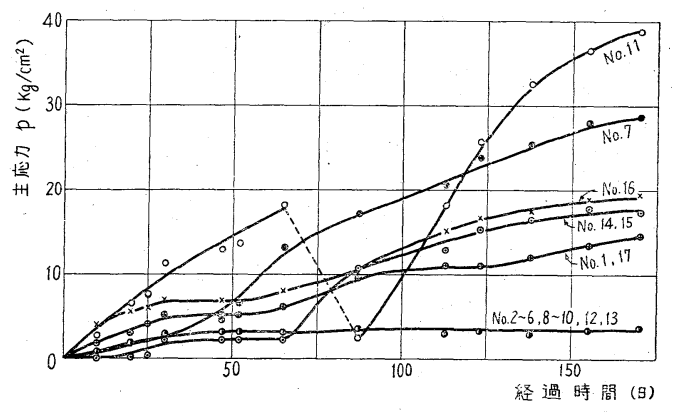

第 7 図大夕張排気立坑の試験用坑底 連接部に和计る測定結果 
分には，僅かであるが鉛直方向の応力が現われているこ とである。これは切上りが図唀されただけの高さしか なく，その上に矢木を並べて，天井の地圧がこれに作用 できるようにしてあることによるものと想像される。

\section{6. 奔別礦業所中央立坑における測定}

この立坑は奔別坑之弥生坑との中間の帽内頁岩層の中 北開さくされたものであるが，この付近には二つの大き な断層が走つて特り，そのため地層は激しく乱され，注 とんぞ層理が見分けられない位である。第 8 図は立坑， 炭層特よび断層の相対位置を示す。したがつて，かなり 高い地圧がライニングに作用するすの之想像されるので 内外 2 層のコンクリートブロックをるつてライニングさ れた。

外側のブロックはセメントと焼硬を $1: 7$ の比率で配 合した弱いコンクリート(強さは $55 \mathrm{~kg} / \mathrm{cm}^{2}$ 程度) でで きて招り，しかも，第 9 因左下方に示したような形状寸 法を有し，中空である。内側のブロックは配合比 $1: 2$ : 4 のコンクリートでできて拈り，その強さは約 $400 \mathrm{~kg} /$ $\mathrm{cm}^{2}$ で，第 9 図右下注したような形状，寸法を有して いる。内外のブロックの間には $1: 3$ の配合のセメント モルタル層 $(1 \mathrm{~cm})$ を置き，水の浸透を防いでいる。裏 込めにもブロック間の目地にも同じセメントモルタルが 用いられている。したがつて，このライニングは風性構 造であるが，地圧によつて一たん外側のブロックが破壞 すると可縮構造となる。坑口付近は湧水が多かつたが， それ以下は比較的少なく，水止めがよく行なわれたの で, ライニングの内壁は畭燥している。

測定片はライニング内壁の一つの母線上に，深さ 9.83 $\mathrm{m}$ ごとに 1 個ずつ，埋設された。浅い部分には中空測定 片が埋設されたが，間もなく破壊したので，それ以下に は中実測定片が埋設された。立坑の深さは $550 \mathrm{~m}$ である

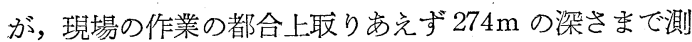
定片が埋設された。それ以下は立坑完成後測定片を埋設 して測定が行なわれることになつた。この立坑での応力 測定は改良された光弾性装置をもつて行なわれ，したが つて, 等色線模様からではなく, 補整器の読みから応力 が求められた。

1 年半以上にわたる測定の結果は第10図に示すようで

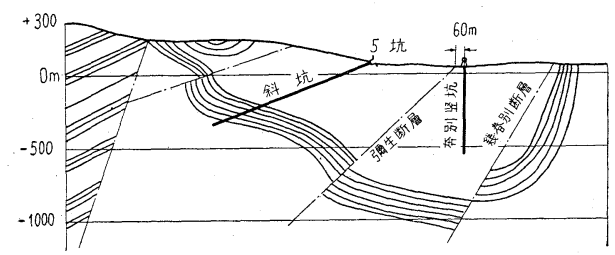

第 8 図 奔別矿業所中央立坑と炭層と 断層との関係位置図

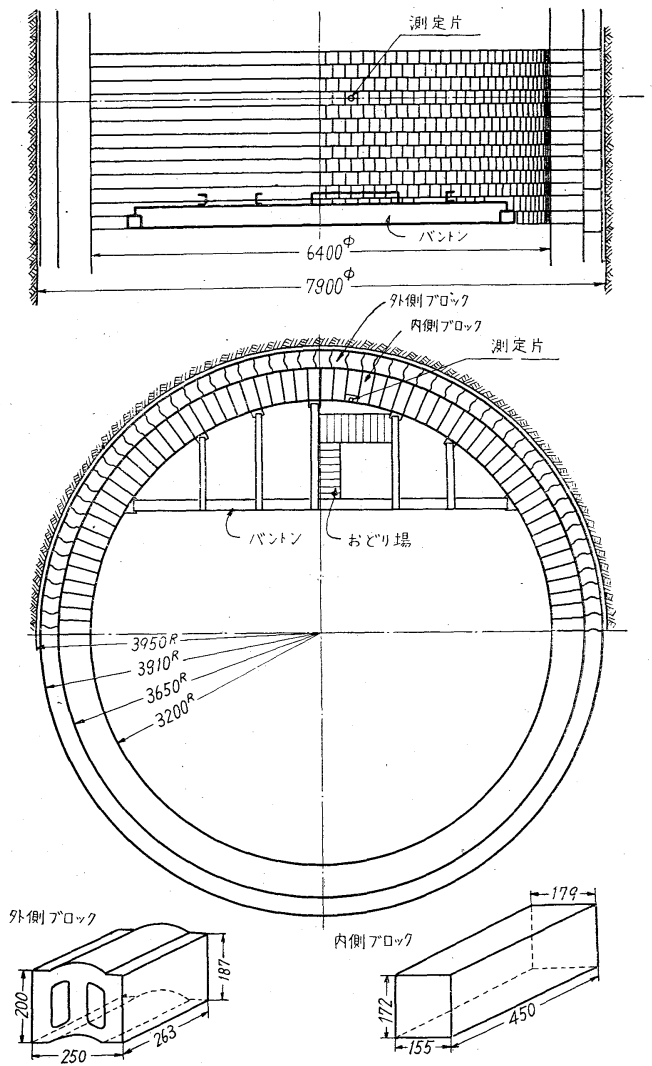

第 9 図 奔別砸業所中央立坑のライニングの構造

ある。この四からライニングに現われる応力，したがつ て，ライニングに作用する地圧は，一般に，最初一たん 增加するが，その後，不規則汇変動し，やがて減小の傾 向を示している。しかし，今までに測定した立坑の中で 最る高い応力が現われていることに注目される。また， 応力は深さに無関係で，地艋の良否に直接関係するよう である。

応才が時間とともに变動するのは，㰸弱地盤中開宊 くされた空洞のライニングに特有の現象ではないかと考 えられる。これに似た例を挙げると，高松炭砸二島砸業 所坑底水平坑道のようである。この坑道は歌弱なベント ナイト質凝㕄岩中に開さくされたるので，コンクリート ブロックと松板とを用い，可縮性と可屈性とを持たせて ライニングされたが，完成後約 3 カ月間は断面がいくら゙ 几変形し，その後变形は僅かになり，1年半後には落着 いた由である。

奔別の立坑には $340 \mathrm{~m}$ 之 $550 \mathrm{~m}$ の水準で坑道と連絡す るが，これらの坑道は分岐点から約 $10 \mathrm{~m} の$ 間だけ立坑と 同様に二重のブロックをもつてライニングを施された。 しかし施工後 1〜2 カ月でライニングの一部使壊が現 われた。水平玾首の維持が立坑の維持より，いかに難し いかが分る。 

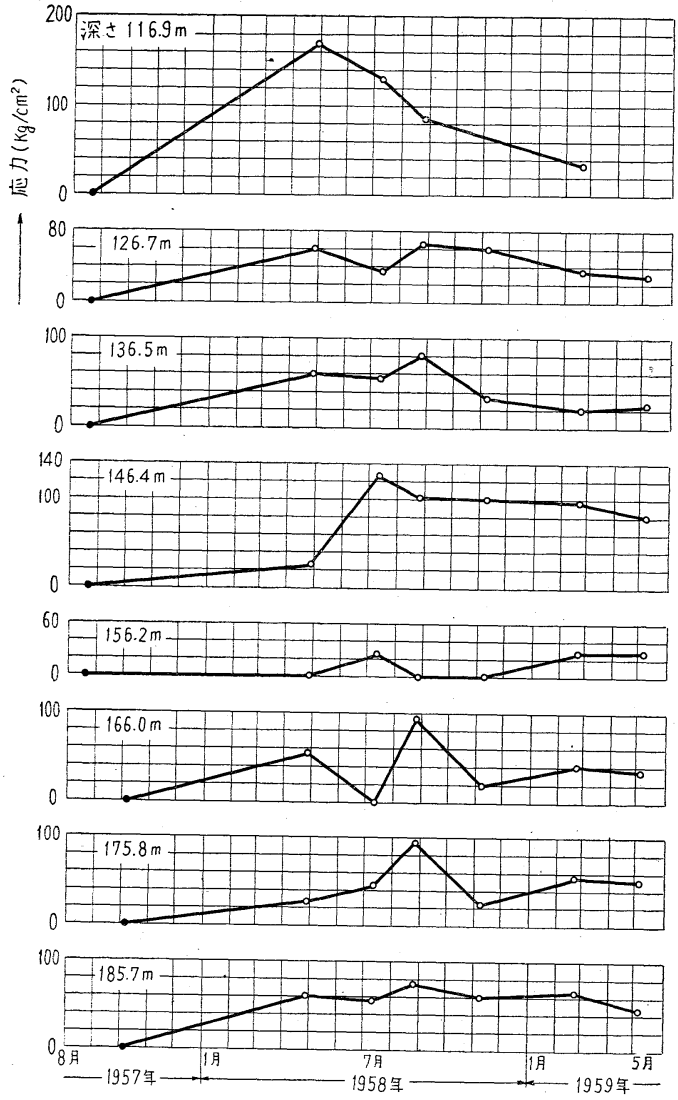
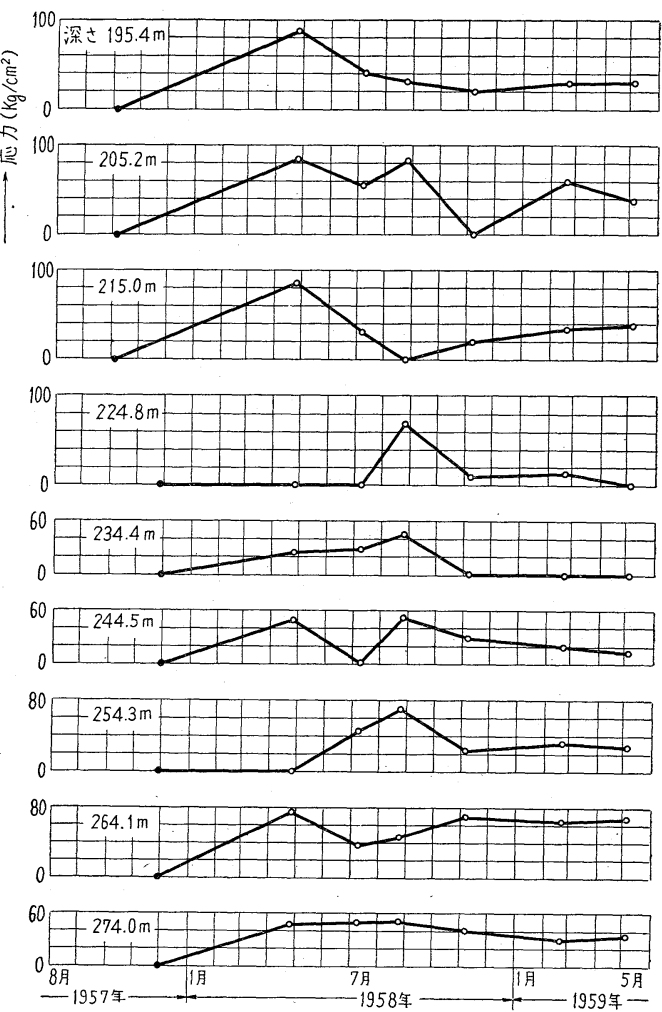

- 测定片埋設時期

○测定値

第10図 奔別砿業所中央立坑ライニングの応力測定結果

\section{7. 結 論}

光弾性を利用する応力計を用い，いくつかの炭鉱の立 坑法いて，数年にわたりライニングに現われる応力を 測定して来た。この測定方法には，現在から見れば不備 な点もあつて, 精度の高い結果は得られなかつたが，炭 鉣の立坑ライニングの応力に関し，拉上そ次の事柄が認 められた。

1）海底の四紀層中の立坑には水平方局に梁さととも に増加する応力が現われ，大体土圧論で計算される程度 の地圧が作用するようと思われる。2) 破砕された地艋 中の立坑ライニングに現われる応力は, 時間的に一たん 増加し, その後変動し, やがて減少の傾向を示しながら 落着くようである。最大応力は各々の湘定䈯所の地盤の 条件によつて暴り，地盤が特に悪いところでは，かなり 高い值に達する。しかし立坑を維持することは同じ条件 の所化，水平坑道を維持するより這かに容易であること いうまでもない。3）岩盤が文夫であれば，応力はゼ口 まては極めて低い。さ注ど丈夫でなくても，連続した弾 性岩盤であれば，深さ数百メートルの立坑であれば剛性
支保で安全に維持できるこの時，いくぶん岩盤が流動 学的性質を有するため, ライニングには, 時間的に増加 する応力が現われるが，やがて数十 $\mathrm{kg} / \mathrm{cm}^{2}$ までの值に 落着くようである。

この研究を緾めるに当り，多忙な立坑開さく現場にお いて応力測定を行なうことと，測定結果を発表すること を許可して頂いた三井銗山株式会社, 三菱釷業株式会社 および住友石炭鉙澲株式会社, ならびに直接測定に協力 して頂いた各社の多数の技術者の方々に厚く御礼申上げ る次第であります。

\section{参、考 文 献}

1) 平松・丹羽・岡 : 光弾性を利用する盤圧の湘定, 日本捈亚会誌71 巻, 799号, (昭和 30 年 1 月) , $11 \sim 14$ 頁

2) 平松・间: 光弾性を利用する地圧測定法の改良, 日本鉱業会誌75 巻, 847号, (昭和 34 年 1 月) $9 \sim 14$ 頁

3) 特に 2 軸応力の場合の測定法に関しては, 平松・丹羽・岡 : 光弹 性応力計による地圧の測定，水㺟会誌14巻 1 号 (昭和34年12月) $7 \sim 10$ 頁

4）厚肉円筒の公式（例兄ば，機械工学便筧 4 102 頁,昭和26年版) を変形したるの

5) Heise-Harbst-Fritzsche: Bergbaukunde II, 7 Auf. 1950, 243 頁

6）平松・网：立坑岩盤の盤圧飞関する実験的研究，日本釷業会誌68 巻, 774号, 昭和 27 年12月, 545 548頁 